\title{
Heat Requirements of Two Layer Strains Placed on Different Dates
}

\section{-Author(s)}

\section{Gencoglan S'}

Department of Biosystem Engineering, Faculty of Agriculture, Kahramanmaras Sutcu Imam University, Kahramanmaras 46060, Turkey

\section{-Mail Address}

Corresponding author e-mail address Serpil Gencoglan

Kahramanmaras Sutcu Imam University, Faculty of Agriculture, Department of Biosystem Engineering, Kahramanmaras, 46060, TURKEY

Phone: +90 (344) 3002075

Email: sgencoglan@ksu.edu.tr

\section{EKeywords}

Heat and moisture production, Heat balance Temperature control, Thermoregulation, Weibull method.

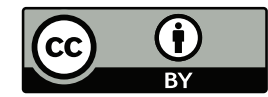

Submitted: 19/January/2018 Approved: 18/February/2018

\section{ABSTRACT}

This study was conducted to calculate the heat requirements of Hy-line W-36 and Hy-line W-98 layer chicks placed on different dates, and to select one of these strains based on heat requirements and egg prices. An environmentally-controlled, mechanically-ventilated, and fan and pad-cooled house with a capacity of 94,500 chicks was designed. Based on the identification of September as the month with the highest egg prices, placement dates were selected $\left(16^{\text {th }}\right.$ of March, $1^{\text {st }}$ of April, $16^{\text {th }}$ of April, $23^{\text {rd }}$ of April and $1^{\text {st }}$ of May) to coincide with economic egg weight in that month. The heat requirements for a rearing period of 35 days of both evaluated strains starting on the above-mentioned dates were calculated using heat and moisture balance method commonly used for livestock and poultry houses. Those placement dates corresponded to economic egg weight dates (with 50-52 g eggs) of $15^{\text {th }}$ of August, $1^{\text {st }}$ of September, $16^{\text {th }}$ of September, $23^{\text {rd }}$ of September and $1^{\text {st }}$ of October. Total heat requirements during the 35-day rearing periods of chicks placed on the identified dates were respectively calculated as 640, 601, 413, 401 and 369 kW/h for Hy-line W-36 and respectively as 778, 732, 551, 539 and 497 kW/h for Hy-line W-98 chicks. September had the highest egg prices for both strains (4.73 and 5.06 US cents/egg). The lowest heat requirement was observed when chicks were placed on the $23^{\text {rd }}$ of April. Hy-line W-36 chicks presented higher total heat requirement than Hy-line W-98 chicks. Therefore, $23^{\text {rd }}$ of April as the most economic placement date and Hy-line W-36 as the most cost-effective layer strain.

\section{INTRODUCTION}

Controlled-environment poultry houses are used for layers to achieve optimum yields, to rear more layers per unit of space and for better control of indoor climate conditions. In particular, young chicks are very susceptible to environmental conditions. The objective of environmental control is to maintain indoor temperatures, humidity, air movement, lighting, as well as gas, dust and odor emissions within the specified limits (Seedorf et al., 1998; Garcimartin et al., 2007). Environmental control is applied not only to maximize production, but also to minimize the stresses to which animals and workers are subjected inside the poultry house. Indoor environmental conditions significantly influence animal health, behavior, nutrition, heat and moisture generation, production efficiency and quality, human health, as well as the structural characteristics and costs of housing (Şekerden \& Özkütük, 1991).

Hen egg yield potential is achieved when optimal environmental conditions provided during the rearing and egg production stages, as well as sufficient nutrition and specific management practices (Çolak, 
2006). In order to achieve high yield in livestock or poultry operations, either the proper environmental conditions should be supplied for specific genotypes or the genotypes suitable for available conditions should be selected. Different animal species and strains have different adaptation capacities to climate conditions. In other words, animals with different genetics may have different reactions in a specific environment (Sağgöz, 1997).

Temperature and relative humidity are the most significant environmental parameters for chicks. Since feathering is still not well developed during the first weeks of age and poultry do not have sweat glands, temperature is the most significant environmental factor for chick survival. Depending on the strain, feathering development commonly occurs between 3-6 weeks of age (Peitz, 2007). As chicks are not able to maintain their body temperature, they need to be provided with high temperatures and balanced and protein-rich diets during that period (Maton et al., 1985; Von Wachenfelt et al., 2001; Peitz, 2007; Ugwuishiwu et al., 2014). Optimal indoor temperature should be between $32-38^{\circ} \mathrm{C}$ during the first weeks of rearing, and then reduced to $15-25^{\circ} \mathrm{C}$ after 5 weeks of age (FASS, 2010). Initial temperatures of $32-35^{\circ} \mathrm{C}$ were recommended by Wathes \& Charles (1994) and of $32^{\circ} \mathrm{C}$ by Şenköylü (2001). These temperatures are reduced by $2.5-3^{\circ} \mathrm{C}$ per week to reach $15-18^{\circ} \mathrm{C}$ in the fifth week. The initial temperatures in the first three days of life of Hy-line W-36 (white) and Hy-line W-98 (brown) commercial layer chicks should be $32-33^{\circ} \mathrm{C}$ and $33-36^{\circ} \mathrm{C}$, respectively, and should be reduced by $2-3^{\circ} \mathrm{C}$ per week to $21^{\circ} \mathrm{C}$ at the end of the fifth week, according to Hy-Line (2012-2016). Lindley \& Whitaker (1996) indicated that the initial indoor temperature of $35^{\circ} \mathrm{C}$ should gradually be reduced to $24^{\circ} \mathrm{C}$ during first two weeks.

Relative humidity should be between $40-60 \%$ for layer chicks. The relative humidity should be around $60 \%$ during the first days and then should be reduced to minimum 40\% (Hy-Line 2012-2016). A relative humidity of about $50-60 \%$ should be supplied to chicks to allow for sufficient and timely feathering (Şenköylü, 2001). Low relative humidity levels may result in excessive water loss and respiratory diseases in chicks (Türkoğlu \& Sarıca, 2009). Relative humidity levels below $30 \%$ increase discomfort and aggression in animals. On the other hand, excessive relative humidity results in wet litter, increased ammonia concentrations, poor air quality and intestinal diseases (Hy-Line, 2012; Uğurlu \& Kara, 2002).
Since poultry are homeothermic creatures, they can maintain their body temperature constant for a long time despite large fluctuations in ambient temperature. The heat generation of animals fed feeds of adequate energy content is almost constant and the temperature interval created by heat generation is called as thermoneutral zone (CIGR, 1984). When animals are maintained in this age-dependent zone, metabolic heat generation and energy consumption are low, and the animals do not use any energy for heat loss or gain, and therefore, are more efficient in terms of production. When the body temperature of animals is within the thermoneutral zone, they utilize the energy obtained from the diet for growth, reproduction and development of immune system (Daghir, 2008). When the temperature is below the thermoneutral temperature, animals use dietary energy for heat generation rather than for growth and development, and increase their feed consumption. The extra energy is used to regulate body temperature instead of being used to gain weight (Hurwitz \& Bengal, 1982; Scott et al., 1983; Yahav et al., 1996). Henken et al. (1983) carried out a physiology study with 3- to 6-week-old turkeys and reported $12.9 \%$ and $10.5 \%$ higher feed intake at environmental temperatures of $15^{\circ} \mathrm{C}$ and between $10-20^{\circ} \mathrm{C}$, respectively, than at $25^{\circ} \mathrm{C}$. At low temperatures, animals try to reduce their body surface area and respiration rate, increase their motion, and group together. In addition, low temperatures cause continuous muscle contractions and trembling in animals (Demirören, 2007).

It is essential to keep indoor temperatures within the thermoneutral zone for optimal chick growth and comfort. Therefore, chicks require rearing until a certain age. Heat requirements and egg prices should be taken into consideration to identify the best rearing seasons and to select the proper strains.

The objective of this study was to determine the indoor heat requirements during a 35-day rearing period of Hy-line W-36 and Hy-line W-98 layer chicks placed on different dates. Based on heat requirements and egg prices paid to the producer, estimated values were used to identify the most cost-effective rearing period and strain for egg production.

\section{MATERIAL AND METHODS}

It was assumed that Hy-line W-36 and Hy-line W-98 chicks were grown in rearing houses for 17 weeks and then transferred to laying houses (Şenköylü, 2001; Hyline, 2016a), reaching 50-52 g egg weight at 20weeks 
of age. Monthly egg prices (between the years 20102015) paid to producers for white and brown eggs were calculated based on the white and brown egg prices on different days of the month obtained from the records of Egg Producers Central Association (YumBir, 2017b). Following the identification of September as the month with the highest egg prices, the dates of placement were determined to achieve egg production in this month as $16^{\text {th }}$ of March, $1^{\text {st }}$ of April, $16^{\text {th }}$ of April, $23^{\text {rd }}$ of April, and $1^{\text {st }}$ of May.

In order to determine the heat requirements of Hy-line W-36 and Hy-line W-98 laying strains, an environmentally-controlled, mechanically-ventilated, fan-pad cooled rearing house with a capacity of 94,500 chicks was designed. The house was 82-m long, 15-m wide (Şenköylü, 1991), 4-m high. Chicks were placed in groups of 30 chicks each in $120 \times 67-\mathrm{cm}$ cages (Güres Teknoloji, 2017). Five-story cages were arranged in five rows (1.7-m wide rows) with 1.0-m spacing (Figure 1). It was assumed that Hy-line W-36 and Hy-line W-98 layer chicks would be placed on the $16^{\text {th }}$ of March, $1^{\text {st }}$ of April, $16^{\text {th }}$ of April, $23^{\text {rd }}$ of April and $1^{\text {st }}$ of May and that the housed would be heated for 35 days.

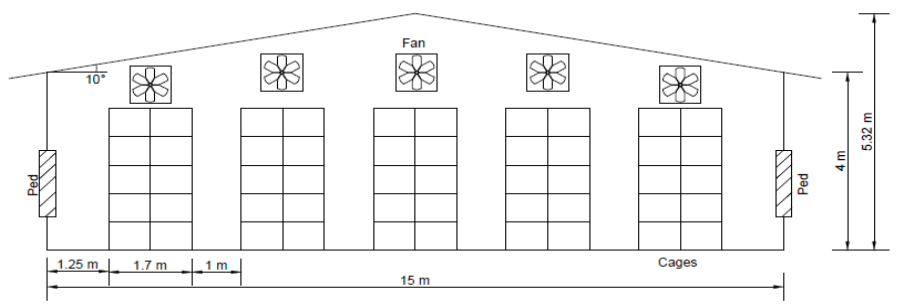

Figure 1 - Cross-section of the rearing house.

In rearing house, a $268-\mathrm{cm}^{2}$ cage area was allocated to each chick (Güdar Yem, 2011; Hy-line, 2012). Total ventilation opening size was $13 \%$ of total floor area (Öneş \& Olgun, 1989). The angle of gable roof was 10 (Ekmekyapar, 1993; İzocam-Tekiz, 2016). Polyurethane-insulated galvanized sandwich panels (5-cm thick) with $40-42 \mathrm{~kg} / \mathrm{m}^{2}$ density and $0.022 \mathrm{~W} /$ $\mathrm{m}^{20} \mathrm{C}$ heat transfer coefficient were used in the roof and walls of the house (izocam-Tekiz, 2016, Panelsan, 2016). The heat transfer coefficient of the PVC door and pad caps was $5 \mathrm{~W} / \mathrm{m}^{20} \mathrm{C}$, and of the 1 -mmthick fan caps was $5.82 \mathrm{~W} / \mathrm{m}^{2 \circ} \mathrm{C}$ (Table 1) (Şahin \& Ünal, 2005).
The following heat balance equations were used to calculate the heat requirements of chicks on days 1 , 2, 4, 6, 8, 10, 14, 21, 28 and 35 (Lindley \& Whitaker, 1996; Öztürk, 2003; Gençoğlan \& Başpınar, 2016).

$\mathrm{Qm} \geq \leq \mathrm{q}_{\mathrm{s}}+\mathrm{q}_{\mathrm{v}}$

Where Qm: sensible heat released by the chicks to ambient $(W), q_{s}$ : total heat loss through structural members (roof, wall, door, fan, pad) (W), $\mathrm{q}_{\mathrm{v}}$ : heat loss through ventilation $(\mathrm{W})$.

Heat balance is not always achieved with this equation. If $Q m<q_{s}+q_{v^{\prime}}$ there is a heat deficit. Either heat losses should be prevented or extra heat should be provided to bring the heat balance to an optimum level. If $Q m>q_{s}+q_{v^{\prime}}$ then there is overheating. In this case, excess heat can be removed through ventilation.

Heat loss through the structural members $\left(q_{y}\right)$ was calculated by using the following equation:

$q_{y}=\Sigma U \cdot A \cdot \Delta t$.

Where $\Sigma \mathrm{U}$ : total heat transfer coefficient of structural members $\left(\mathrm{W} / \mathrm{m}^{2}{ }^{\circ} \mathrm{C}\right), \mathrm{A}$ : surface area of structural members $\left(\mathrm{m}^{2}\right), \Delta \mathrm{t}=\mathrm{ti}-\mathrm{to}$, where ti is indoor and to is outdoor temperature $\left({ }^{\circ} \mathrm{C}\right)$.

Total heat transfer coefficient of structural members $(U)$ was calculated by using the following equation:

$$
U=\frac{1}{\frac{1}{f i}+\sum_{i=1}^{n} \frac{d i}{k i}+\frac{1}{f_{O}}}
$$

Where fi and fo: surface heat transfer coefficient of the inner and outer surfaces (conductance) $\left(\mathrm{W} / \mathrm{m}^{2}\right.$ $\left.{ }^{\circ} \mathrm{C}\right), \mathrm{d}(\mathrm{m})$ and $\mathrm{k}\left(\mathrm{W} / \mathrm{m}^{\circ} \mathrm{C}\right)$ are, respectively, structural member thickness and heat transmission coefficient (conductivity).

Heat loss through ventilation from the layer chick rearing house was calculated by the following equation:

$\mathrm{qv}=0.341{ }^{*} \mathrm{Q} * \Delta \mathrm{t}$

Where qv: heat loss through ventilation (W), 0.341 is the amount of heat required to increase temperature of $1 \mathrm{~m}^{3} \mathrm{of}$ air by $1{ }^{\circ} \mathrm{C}\left(\mathrm{W} \cdot \mathrm{h} / \mathrm{m}^{30} \mathrm{C}\right), \mathrm{Q}$ : minimum air flow rate $\left(\mathrm{m}^{3} / \mathrm{h}\right), \Delta \mathrm{t}=$ ti-to, where ti is indoor and to is outdoor temperature $\left({ }^{\circ} \mathrm{C}\right)$.

Table 1 - Heat transfer coefficient and surface areas of structural members of the designed house

\begin{tabular}{llcc}
\hline $\begin{array}{l}\text { Structural } \\
\text { Members }\end{array}$ & Materials & $\begin{array}{c}\text { Heat Transfer Coefficient } \\
(\mathrm{U})\left(\mathrm{w} / \mathrm{m}^{2 \circ} \mathrm{C}\right)\end{array}$ & $\begin{array}{c}\text { Surface Areas of } \\
\text { Structural Members }\left(\mathrm{m}^{2}\right)\end{array}$ \\
\hline Roof & Polyurethane-insulated 3-5 trapezoidal galvanized sandwich panels & 0.022 & 1248.04 \\
Door & $2(1.9 \times 2.0 \mathrm{~m})$ PVC doors & 5.00 & 7.60 \\
Pad & Over 2 sidewalls, 2x(1.5x42m) PVC-capped 126 m² pad & 5.00 & 126.00 \\
Wall & Polyurethane-insulated blind screw galvanized sandwich panel & 0.022 & 626.92 \\
Fan & Over back wall, 18 fans (1.4x1.4 m) with 1 mm metal caps & 5.82 & 35.28 \\
\hline
\end{tabular}


Ventilation applied to control humidity should be based on moisture balance. The minimum air flow rate, $\mathrm{Q}\left(\mathrm{m}^{3} / \mathrm{h}\right)$, required to maintain the indoor moisture constant within the design criteria for the layer chick rearing house was calculated by the following equation (Timmons \& Gates, 1987; Albright, 1990; ASAE, 1994).

$$
Q=\frac{\sum w a}{q i-q o}
$$

Where $\sum$ wa : total amount of water vapor released by chicks (g/h), qi-qo: absolute humidity of indoor and outdoor air $\left(\mathrm{g} / \mathrm{m}^{3}\right)$.

For heat and moisture balance calculations of the poultry house, long-term (1980-2016) monthly average temperature and the relative humidity values of Kahramanmaraş province were taken into consideration (Figure 2). Long-term climate data were subjected to Weibull distribution to determine temperature and relative humidity values at $80 \%$ probability for the evaluated rearing seasons, including March-April-May-June (Tülücü, 1988).

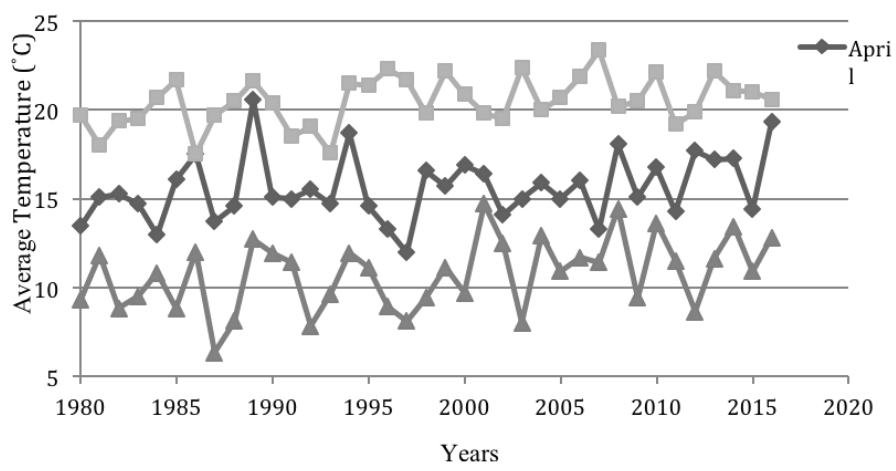

Figure $\mathbf{2}$ - Long-term monthly average temperature and relative humidity values

In order to calculate heat and moisture balance, indoor temperature and relative humidity values and weekly mortality rates were obtained from Hy-line, 2012and the genetic line manual (Hy-Line 2016), presented in Table 2, were used.

Since the rearing house was environmentcontrolled, mortality rates were generally assumed to increase from the $4^{\text {th }}$ day. The mortality rate of Hy-line W-36 hens ranged from $1 \%$ on days $4-7$ to $1.8 \%$ ondays29-35. The mortality rate for Hy-line W-98 hens ranged from $0.5 \%$ on days $4-7$ to $1 \%$ ondays $29-35$. Mortality numbers and dead animals were not included in the heat and moisture balance calculations. Number of dead birds on days $1,2,4,6,8,10,14,21,28$ and 35 were respectively calculated as $10,10,460,465$, 467, 468, 468, 1474, 1541 and 1604 (a total of 6967 birds) for Hy-line W-36 and as 10, 10, 226, 226, 220, $219,219,747,834$ and 918 (a total of 3629 of birds) for Hy-line W-98. For a poultry house with a capacity of 94,500 chicks, number of surviving chicks was calculated as 87,533 for Hy-line W-36 and as 90,871 for Hy-line W-98.

According to Hy-line (2012-2016), indoor relative humidity was setat $60 \%$ for the first seven days and at $50 \%$ for the remaining experimental days. Relative humidity values are presented in Table 2.For heat requirement calculations of the two layer strains, indoor temperature values of 32.2, 31.1, 30, 28.9, 27.8, 25.6, 22.8 and $21.1^{\circ} \mathrm{C}$, specified in Chepete \& Xin, (2004) and Chepete et al. (2004), were used and the heat released by chicks at these temperatures are presented in Table 3.

\section{RESULTSAND DISCUSSION}

The indoor heat requirements up to 35 days of age of Hy-line W-36 and Hy-line W-98 layer chicks placed on five different dates $\left(16^{\text {th }}\right.$ of March, $1^{\text {st }}$ of April, $16^{\text {th }}$ of April, $23^{\text {rd }}$ of April, $1^{\text {st }}$ of May) were calculated. The most cost-effective rearing period was identified and one of the two strains was selected based on its heat requirements and producer average egg prices.

Analyses of the long-term climate data (1980-2016) revealed temperature values, at $80 \%$ probability, of 12.4, 17.2, 21.5 and $27.1{ }^{\circ} \mathrm{C}$ for March, April, May and June respectively, and relative humidity values of65.3, 63.2, 58.7 and 55\%, respectively. Based on

Table 2 - Optimal temperature, relative humidity requirements and mortality rates of Hy-line W-36 and Hy-line W-98 during the first 35 days of life.

\begin{tabular}{|c|c|c|c|c|c|c|}
\hline Environmental Factors & 0-3 Days & 4-7 Days & 8-14 Days & 15-21 Days & 22-28 Days & 29-35 Days \\
\hline \multicolumn{7}{|l|}{ Hy-line W-36 strain } \\
\hline Temperature $\left({ }^{\circ} \mathrm{C}\right)$ & $32-33$ & $30-32$ & $28-30$ & $26-28$ & $23-26$ & $21-23$ \\
\hline Relative Humidity (\%) & 60 & 60 & $\operatorname{Min} 40$ & $\operatorname{Min} 40$ & $\operatorname{Min} 40$ & $\operatorname{Min} 40$ \\
\hline Mortality Rate (\%) & & 1 & 1.5 & 1.6 & 1.7 & 1.8 \\
\hline \multicolumn{7}{|l|}{ Hy-line W-98 strain } \\
\hline Temperature $\left({ }^{\circ} \mathrm{C}\right)$ & $33-36$ & $30-32$ & $28-30$ & $26-28$ & $23-26$ & $21-23$ \\
\hline Relative Humidity (\%) & 60 & 60 & Min 40 & Min 40 & Min 40 & Min 40 \\
\hline Mortality Rate (\%) & & 0.5 & 0.7 & 0.8 & 0.9 & 1 \\
\hline
\end{tabular}


Table 3 - Climate data used to provide indoor environmental conditions.

\begin{tabular}{|c|c|c|c|c|c|c|c|c|c|c|c|}
\hline \multirow{2}{*}{ Days } & \multirow{2}{*}{$\begin{array}{l}\text { Weight } \\
(\mathrm{kg})\end{array}$} & \multicolumn{2}{|c|}{ Sensible Heat (w/kg) } & \multicolumn{2}{|c|}{$\begin{array}{c}\text { Water Vapor } \\
\text { Production (g/kg.h) }\end{array}$} & \multicolumn{3}{|c|}{ Temperature $\left({ }^{\circ} \mathrm{C}\right)$} & \multicolumn{3}{|c|}{ Absolute Humidity $\left(\mathrm{g} / \mathrm{m}^{3}\right)$} \\
\hline & & W-36 & W-98 & W-36 & W-98 & $\begin{array}{c}\text { Indoor } \\
\text { (ti) }\end{array}$ & $\begin{array}{l}\text { Outdoor } \\
\text { (to) }\end{array}$ & $\begin{array}{l}\text { Difference } \\
\text { (ti-to) }\end{array}$ & $\begin{array}{c}\text { Indoor } \\
\text { (qi) }\end{array}$ & $\begin{array}{c}\text { Outdoor } \\
\text { (qo) }\end{array}$ & $\begin{array}{c}\text { Difference } \\
\text { (qi-qo) }\end{array}$ \\
\hline \multicolumn{12}{|c|}{ Criteria used for the period started on $16^{\text {th }}$ of March } \\
\hline 1. & 0.04 & 1.50 & -2.40 & 8.67 & 18.96 & 32.20 & 12.40 & 19.80 & 20.59 & 7.20 & 13.39 \\
\hline 2. & 0.04 & 3.90 & 1.50 & 9.99 & 16.46 & 32.20 & 12.40 & 19.80 & 20.59 & 7.20 & 13.39 \\
\hline 4. & 0.06 & 4.00 & 2.80 & 13.08 & 19.98 & 31.10 & 12.40 & 18.70 & 19.38 & 7.20 & 12.18 \\
\hline 6. & 0.06 & 4.60 & 3.40 & 14.40 & 20.57 & 31.10 & 12.40 & 18.70 & 19.38 & 7.20 & 12.18 \\
\hline 8. & 0.07 & 5.80 & 4.70 & 13.96 & 18.66 & 30.00 & 12.40 & 17.60 & 15.13 & 7.20 & 7.93 \\
\hline 10. & 0.07 & 6.40 & 6.90 & 12.93 & 16.02 & 28.90 & 12.40 & 16.20 & 14.33 & 7.20 & 7.13 \\
\hline 14. & 0.09 & 7.40 & 7.10 & 11.90 & 12.64 & 27.80 & 12.40 & 15.40 & 13.53 & 7.20 & 6.33 \\
\hline 21. & 0.18 & 6.60 & 7.50 & 10.87 & 10.73 & 25.60 & 17.20 & 8.40 & 11.92 & 9.33 & 2.59 \\
\hline 28. & 0.27 & 6.40 & 7.00 & 8.82 & 8.82 & 22.80 & 17.20 & 5.60 & 10.23 & 9.33 & 0.90 \\
\hline 35. & 0.35 & 5.50 & 7.60 & 7.20 & 6.91 & 21.10 & 17.20 & 3.90 & 9.25 & 9.33 & -0.08 \\
\hline \multicolumn{12}{|c|}{ Criteria used for the period started on $1^{\text {st }}$ of April } \\
\hline 1. & 0.04 & 1.50 & -2.40 & 8.67 & 18.96 & 32.20 & 17.20 & 15.00 & 20.59 & 9.33 & 11.26 \\
\hline 2. & 0.04 & 3.90 & 1.50 & 9.99 & 16.46 & 32.20 & 17.20 & 15.00 & 20.59 & 9.33 & 11.26 \\
\hline 4. & 0.06 & 4.00 & 2.80 & 13.08 & 19.98 & 31.10 & 17.20 & 13.90 & 19.38 & 9.33 & 10.05 \\
\hline 6. & 0.06 & 4.60 & 3.40 & 14.40 & 20.57 & 31.10 & 17.20 & 13.90 & 19.38 & 9.33 & 10.05 \\
\hline 8. & 0.07 & 5.80 & 4.70 & 13.96 & 18.66 & 30.00 & 17.20 & 12.80 & 15.13 & 9.33 & 5.80 \\
\hline 10. & 0.07 & 6.40 & 6.90 & 12.93 & 16.02 & 28.90 & 17.20 & 11.70 & 14.33 & 9.33 & 5.00 \\
\hline 14. & 0.09 & 7.40 & 7.10 & 11.90 & 12.64 & 27.80 & 17.20 & 10.60 & 13.53 & 9.33 & 4.20 \\
\hline 21. & 0.18 & 6.60 & 7.50 & 10.87 & 10.73 & 25.60 & 17.20 & 8.40 & 11.92 & 9.33 & 2.59 \\
\hline 28. & 0.27 & 6.40 & 7.00 & 8.82 & 8.82 & 22.80 & 17.20 & 5.60 & 10.23 & 9.33 & 0.90 \\
\hline 35. & 0.35 & 5.50 & 7.60 & 7.20 & 6.91 & 21.10 & 21.50 & -0.40 & 9.25 & 11.13 & -1.88 \\
\hline \multicolumn{12}{|c|}{ Criteria used for the period started on $16^{\text {th }}$ of April } \\
\hline 1. & 0.04 & 1.50 & -2.40 & 8.67 & 18.96 & 32.20 & 17.20 & 15.00 & 20.59 & 9.33 & 11.26 \\
\hline 2. & 0.04 & 3.90 & 1.50 & 9.99 & 16.46 & 32.20 & 17.20 & 15.00 & 20.59 & 9.33 & 11.26 \\
\hline 4. & 0.06 & 4.00 & 2.80 & 13.08 & 19.98 & 31.10 & 17.20 & 13.90 & 19.38 & 9.33 & 10.05 \\
\hline 6. & 0.06 & 4.60 & 3.40 & 14.40 & 20.57 & 31.10 & 17.20 & 13.90 & 19.38 & 9.33 & 10.05 \\
\hline 8. & 0.07 & 5.80 & 4.70 & 13.96 & 18.66 & 30.00 & 17.20 & 12.80 & 15.13 & 9.33 & 5.80 \\
\hline 10. & 0.07 & 6.40 & 6.90 & 12.93 & 16.02 & 28.90 & 17.20 & 11.70 & 14.33 & 9.33 & 5.00 \\
\hline 14. & 0.09 & 7.40 & 7.10 & 11.90 & 12.64 & 27.80 & 17.20 & 10.60 & 13.53 & 9.33 & 4.20 \\
\hline 21. & 0.18 & 6.60 & 7.50 & 10.87 & 10.73 & 25.60 & 21.50 & 4.10 & 11.92 & 11.13 & 0.79 \\
\hline 28. & 0.27 & 6.40 & 7.00 & 8.82 & 8.82 & 22.80 & 21.50 & 1.30 & 10.23 & 11.13 & -0.90 \\
\hline 35. & 0.35 & 5.50 & 7.60 & 7.20 & 6.91 & 21.10 & 21.50 & -0.40 & 9.25 & 11.13 & -1.88 \\
\hline \multicolumn{12}{|c|}{ Criteria used for the period started on $23^{\text {rd }}$ of April } \\
\hline 1. & 0.04 & 1.50 & -2.40 & 8.67 & 18.96 & 32.20 & 17.20 & 15.00 & 20.59 & 9.33 & 11.26 \\
\hline 2. & 0.04 & 3.90 & 1.50 & 9.99 & 16.46 & 32.20 & 17.20 & 15.00 & 20.59 & 9.33 & 11.26 \\
\hline 4. & 0.06 & 4.00 & 2.80 & 13.08 & 19.98 & 31.10 & 17.20 & 13.90 & 19.38 & 9.33 & 10.05 \\
\hline 6. & 0.06 & 4.60 & 3.40 & 14.40 & 20.57 & 31.10 & 17.20 & 13.90 & 19.38 & 9.33 & 10.05 \\
\hline 8. & 0.07 & 5.80 & 4.70 & 13.96 & 18.66 & 30.00 & 21.50 & 8.50 & 15.13 & 11.13 & 4.00 \\
\hline 10. & 0.07 & 6.40 & 6.90 & 12.93 & 16.02 & 28.90 & 21.50 & 7.40 & 14.33 & 11.13 & 3.20 \\
\hline 14. & 0.09 & 7.40 & 7.10 & 11.90 & 12.64 & 27.80 & 21.50 & 6.30 & 13.53 & 11.13 & 2.39 \\
\hline 21. & 0.18 & 6.60 & 7.50 & 10.87 & 10.73 & 25.60 & 21.50 & 4.10 & 11.92 & 11.13 & 0.79 \\
\hline 28. & 0.27 & 6.40 & 7.00 & 8.82 & 8.82 & 22.80 & 21.50 & 1.30 & 10.23 & 11.13 & -0.91 \\
\hline 35. & 0.35 & 5.50 & 7.60 & 7.20 & 6.91 & 21.10 & 21.50 & -0.40 & 9.25 & 11.13 & -1.88 \\
\hline \multicolumn{12}{|c|}{ Criteria used for the period started on $1^{\text {st }}$ of May } \\
\hline 1. & 0.04 & 1.50 & -2.40 & 8.67 & 18.96 & 32.20 & 21.50 & 10.70 & 20.59 & 11.13 & 9.46 \\
\hline 2. & 0.04 & 3.90 & 1.50 & 9.99 & 16.46 & 32.20 & 21.50 & 10.70 & 20.59 & 11.13 & 9.46 \\
\hline 4. & 0.06 & 4.00 & 2.80 & 13.08 & 19.98 & 31.10 & 21.50 & 9.60 & 19.38 & 11.13 & 8.24 \\
\hline 6. & 0.06 & 4.60 & 3.40 & 14.40 & 20.57 & 31.10 & 21.50 & 9.60 & 19.38 & 11.13 & 8.24 \\
\hline 8. & 0.07 & 5.80 & 4.70 & 13.96 & 18.66 & 30.00 & 21.50 & 8.50 & 15.13 & 11.13 & 4.00 \\
\hline 10. & 0.07 & 6.40 & 6.90 & 12.93 & 16.02 & 28.90 & 21.50 & 7.40 & 14.33 & 11.13 & 3.20 \\
\hline 14. & 0.09 & 7.40 & 7.10 & 11.90 & 12.64 & 27.80 & 21.50 & 6.30 & 13.53 & 11.13 & 2.39 \\
\hline 21. & 0.18 & 6.60 & 7.50 & 10.87 & 10.73 & 25.60 & 21.50 & 4.10 & 11.92 & 11.13 & 0.79 \\
\hline 28. & 0.27 & 6.40 & 7.00 & 8.82 & 8.82 & 22.80 & 21.50 & 1.30 & 10.23 & 11.13 & -0.91 \\
\hline 35. & 0.35 & 5.50 & 7.60 & 7.20 & 6.91 & 21.10 & 27.10 & -6.00 & 9.25 & 14.32 & -5.07 \\
\hline
\end{tabular}


these outdoor temperature and relative humidity values, absolute humidity values were calculated. Absolute humidity values of $7.20,9.33,11.13$ and $14.32 \mathrm{~g} / \mathrm{m}^{3}$ were calculated for March, April, May and June, respectively (Table 3 ).

Rearing periods of Hy-line W-36 and Hy-line W-98 chicks started on $16^{\text {th }}$ of March, $1^{\text {st }}$ of April, $16^{\text {th }}$ of April, $23^{\text {rd }}$ of April and $1^{\text {st }}$ of May in a rearing house with a capacity of 94,500 chicks. Heat requirements were calculated using the heat balance method (Table 4). Negative values indicate heat deficit and positive values indicate heat excess. Heat deficits may be eliminated by extra heating and excessive heat may be removed by ventilation. Since $\mathrm{Qm}<\mathrm{q}_{\mathrm{s}}+\mathrm{q}_{\mathrm{v}^{\prime}}$ extra heating was required during the first 28 days of the 35 day rearing periods started on $16^{\text {th }}$ of March and $1^{\text {st }}$ of April, and during the first 21 days of the rearing periods started on $16^{\text {th }}$ of April, $23^{\text {rd }}$ of April and $1^{\text {st }}$ of May. On the other days, $\mathrm{Qm}>\mathrm{q}_{\mathrm{s}}+\mathrm{q}_{\mathrm{v}}$ and, therefore, ventilation was required. Total heat requirement (THR) of the $16^{\text {th }}$ of March, $1^{\text {st }}$ of April, $16^{\text {th }}$ of April, $23^{\text {rd }}$ of April and $1^{\text {st }}$ of May periods were respectively calculated as 640, 601, 413, 401 and $369 \mathrm{~kW} / \mathrm{h}$ for Hy-line W-36 and respectively as 778, 732, 551, 539 and $497 \mathrm{~kW} / \mathrm{h}$ for Hy-line W-98. Heat requirements decreased with increasing outdoor temperatures and chick growth and ventilation was required after a certain period.

Since both Hy-line W-36 and W-98 chicks placed on the $16^{\text {th }}$ of March and the $1^{\text {st }}$ of April required extra heating for 28 days, these dates were not considered for the determination of placement date. When Hyline W-36 and W-98 chicks were placed on the $23^{\text {rd }}$ of April, their heat requirements in the first week were the same as that required when placed on the $16^{\text {th }}$ of
April. When placed on the $23^{\text {rd }}$ of April and reared until the $1^{\text {st }}$ of May, Hy-line W-36 and Hy-line W-98 heat requirements were, respectively $14.3 \%$ and $9.6 \%$ lower on day 8 and $11.1 \%$ and $10.2 \%$ lower on day 10 compared with those placed on the $16^{\text {th }}$ of April.

As can be inferred from Table 4, the total heat requirement of $\mathrm{Hy}$-line $\mathrm{W}-98$ chicks was higher than that of Hy-line W-36 chicks. The differences between Hy-line W-36 and Hy-line W-98 may be associated with differences in sensible heat value at $32.2^{\circ} \mathrm{C}$ and heat requirement on the first three days. This result is consistent with Chepete \& Xin (2004) and Chepete et al. (2004) and Hy-line, 2012.

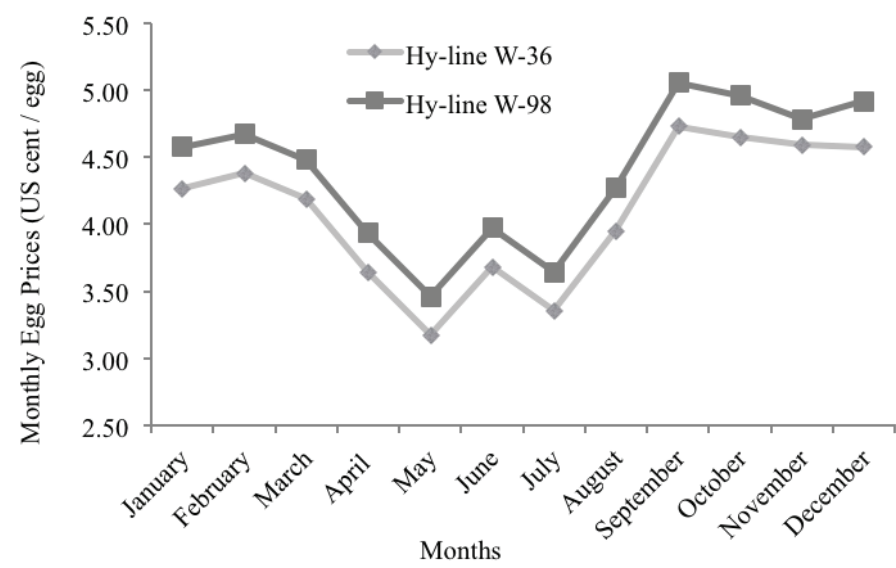

Figure 3 - Monthly average egg prices of Hy-line W-36 and Hy-line W-98 strains.

The highest monthly average egg price (between the years of 2010-2015) was observed in September for both strains. Egg prices decreased from September to May, reached to the lowest prices between May and July and increased again till September (Figure3). Monthly average egg prices of Hy-line W-36 and W-98 strains in September were 4.73 and 5.06 US cents/egg, respectively.

Table 4 - Heat requirements for the first 35 days of age of Hy-line W-36 and W-98 placed on different dates.

\begin{tabular}{|c|c|c|c|c|c|c|c|c|c|c|}
\hline \multirow{4}{*}{ Days } & \multicolumn{10}{|c|}{ Strains } \\
\hline & \multicolumn{5}{|c|}{ Hy-line W-36 } & \multicolumn{5}{|c|}{ Hy-line W-98 } \\
\hline & \multicolumn{5}{|c|}{ Start of Rearing } & \multicolumn{5}{|c|}{ Start of Rearing } \\
\hline & 16 March & 1 April & 16 April & 23 April & 1 May & 16 March & 1 April & 16 April & 23 April & 1 May \\
\hline $1^{\text {st }}$ Day & -29 & -23 & -23 & -23 & -17 & -63 & -55 & -55 & -55 & -47 \\
\hline $2^{\text {nd }}$ Day & -22 & -16 & -16 & -16 & -10 & -44 & -36 & -36 & -36 & -28 \\
\hline $4^{\text {th }}$ Day & -33 & -25 & -25 & -25 & -16 & -61 & -50 & -50 & -50 & -38 \\
\hline $6^{\text {th }}$ Day & -34 & -25 & -25 & -25 & -15 & -59 & -48 & -48 & -48 & -36 \\
\hline $8^{\text {th }}$ Day & -47 & -42 & -42 & -36 & -36 & -78 & -73 & -73 & -66 & -66 \\
\hline $10^{\text {th }}$ Day & -40 & -36 & -36 & -32 & -32 & -53 & -49 & -49 & -44 & -44 \\
\hline $14^{\text {th }}$ Day & -35 & -33 & -33 & -33 & -33 & -43 & -42 & -42 & -42 & -42 \\
\hline $21^{\text {st }}$ Day & -96 & -96 & -212 & -212 & -212 & -80 & -80 & -197 & -197 & -197 \\
\hline $28^{\text {th }}$ Day & -304 & -304 & 256 & 256 & 256 & -298 & -298 & 279 & 279 & 279 \\
\hline $35^{\text {th }}$ Day & 3985 & 185 & 185 & 185 & 185 & 4044 & 258 & 258 & 258 & 336 \\
\hline THR $^{1}$ & -640 & -601 & -413 & -401 & -369 & -778 & -732 & -551 & -539 & -497 \\
\hline
\end{tabular}

'THR: total heat requirement. 
The starting days of the rearing periods to coincide with egg production in September (when the monthly average egg prices are the highest) were identified as the $1^{\text {st }}$ of April, $16^{\text {th }}$ of April and $23^{\text {rd }}$ of April. Total heat requirements for the relevant periods were respectively calculated as 601, 413 and 401 kW/h for Hy-line W-36 and as 732, 551 and 539 kW/h for Hy-line W-98 chicks. The rearing period starting on the $23^{\text {rd }}$ of April had the lowest total heat requirement for both strains (Table4). Total heat requirements of Hy-line W-36 and W-98 placed on the $23^{\text {rd }}$ of April were respectively 2.9 and $2.2 \%$ lower than the heat requirement of those placed on the $16^{\text {th }}$ April. In addition, for chicks placed on the $16^{\text {th }}$ of April, the total heat requirement of $\mathrm{Hy}$ line W-36 chicks was $25.6 \%$ lower that of $\mathrm{Hy}$-line W-98 chicks.

It was concluded that, under the climate conditions of Kahramanmaraş province, as layer chicks placed on the $23^{\text {rd }}$ of April to start laying in September, when the highest monthly average egg prices are paid, present the lowest heat requirement, this is the best date to start rearing layer chicks. Considering the monthly average egg prices and heat requirements of the two evaluated strains, the Hy-line W-36 strain is the most cost-effective for egg production.

\section{ACKNOWLEDGEMENTS}

The author thanks Assoc. Prof. Dr. Zeki Gökalp (a Certified English Translator and an expert in Biosystems Engineering) for his critical reading and through syntactic corrections of the manuscript.

\section{REFERENCES}

Albright LD. Natural ventılation, steady-state energy and mass balances. In: Albrigth LD. Environment control for animals and plants. St Joseph: American Society of Agricultural Engineers;1990. p.143-320.

ASAE - Amerıcan Socıety of Agricultural Engıneers. ASAE agricultural standarts.41 $41^{\text {st }}$ ed. Michigan; 1994.

Chepete HJ, Xin H, Puma MC, Gates RS. Heat and moisture production of poultry and their housing systems: pullets and layers. ASHRAE Transactions 2004;110(2): 286-299.

Chepete HJ, Xin $\mathrm{H}$. Ventilation rates of a laying hen house based on new vs. old heat and moisture production data. Applied Engineering in Agriculture, American Society of Agricultural Engineers 2004;20(6):835842.

CIGR - Commission International du Genie Rural. Climatization of animal houses. Aberdeen: Scottish Farm Buildings Investigation; 1984.

Çolak A. Yumurta cıpiliçlerde 18. Hafta canlı ağırlığı ve uniformities ininverim dönemibazı performanskriterlerineetkileri üzerinde biraraştırma. Istanbul: Selçuk Üniversitesi, Zootekni Bölümü, YüksekLisans Tez, Fen Bilimleri; 2006.
Daghir NJ. Poultry production in hot climates. London: CABI; 2008. p.377.

Demirören E. Hayvandavranışları. II. Baskı. İzmir: Ege Üniversitesi Ziraat Fakültesi Yayınları; 2007. p.272.

Ekmekyapar T, Tarımsalinşaat AÜ. Erzurum: Ziraat Fakültesi Yayınları;1993. p. 197.

FASS - Federation of Animal Science Societies. Guide for the care and use of agricultural animals in research and teaching. $3^{\text {rd }}$ ed. Champaign; 2010. p.30-44.

Garcimartin MA, Ovejero I, Sanchez E, Sanchez-Gıron, V. Application of the sensible heat balance to determine the temperature tolerance of commercial poultry housing.World's Poultry Science Journal 2007;63:575-584

Gençoğlan S, Başpınar A. Determination of the silkworm (Bombyxmori L.) heat requirements in rearing room of village house for optimal environmental conditions, Pakistan. Journal of Zoology 2016;48(2):557561.

Gürdal Yem. Hayvan beslemeel kitabı. Gürdal YemTekstil Hayvan San. ve Tic. A.Ş; 2011

Güres Teknoloji. 2017 [cited 2017 Jan 1]. Available from: http://www. gurestavukculukteknolojisi.com.tr.

Henken AM, Groote Schaarsberg AMJ, Van Der Hel W. The effect of environmental temperature on immune response and metabolism of the young chicken. 4. Effect of environmental temperature on some aspects of energy and protein metabolism. Poultry Science 1983;62:5967.

Hurwitz S, Bengal I. Energy use and performance of young turkeys kept under various constant and cycling environmental temperatures. Poultry Science 1982;61:1082-1086.

Hy-line. Hy-line kahverengi .Performans standartlarıkitapçı̆̆ı. 2012 [cited 2016 Dec. 15]. Available from: https://www.hyline.com/UserDocs/ products/BRN_COM_TUR.pdf.

Hy-line.Hy-line W-36 Commercial layers, management guide. 2016 [cited 2016 Dec. 15]. Available from: http://www.hyline.com/UserDocs/ Pages/36_Com_Eng. Pdf

İzocam-Tekiz. 2016 [cited 2016 Dec. 21]. Available from: http://www.tekiz. com.tr.

Lindley JA, Whitaker JH. Agricultural buildings and structures. St. Joseph: ASAE; 1996.

Maton A, Daelemans J, Lambrecht J. Some fundamentals concerning the construction of animal houses and the building materials to be used In: Maton A, Daelemans J, Lambrecht J. Housing of animals. Amsterdam: Eselvier, 1985. p.321-361

Öneş A, Olgun M. Tarım salyapılardaplanlamave projelendirme kriterleri. Bayındırlık ve İskan Bakanlığı Ankara: Sayi; 1989. p.27-35.

Öztürk T. Tarımsalyapılar. O.M.Ü.ZiraatFakültesi [derskitap, 49]. Samsun; 2003.p.297

Panelsan. Panelsan çatı ve cephe sistemleri. 2016 [cited 2016 Dec 19]. Available from: http://www.panelsan.com.

Peitz L. Tavukçuluk. Ankara: Yrd. Doç. Dr. Ali Karabayar; 2007. p.160.

Sağgöz Y. Farklı iki tip ahır koşullarında barındırılan esmer ve siyah alaca sığırların bazı fizyolojik özellikleri ve performansları [tezi]. Erzurum (TR): Atatürk Üniversitesi Fen Bilimleri Enstitüsü, Zootekni Anabilim Dalı; 1997. 
Şahin A,Ünal HB. Yapı malzeme bilgisi. Izmir: E.Ü. Ziraat Fakültesi Yayın; 2005; p.316.

Scott NR, DeShazer JA, Roller WL. Effect of thermal and gaseous environment on livestock. In: Hellickson MA, Walker JN, editors. Ventilation of agricultural structures. St Joseph: American Society of Agricultural Engineers; 1983. p.121-165.

Seedorf J, Hartung J, Schroder M, Linkert KH, Pedersen S, Takai H, et al. Temperature and moisture conditions in livestock buildings in northern europe. Journal of Agricultural Engineering Research 1998;70:49-57.

Şekerden Ö, Özkütük K. Büyük başhay vanyetiştirme. Samsun: Ondokuz Mayıs Üniversitesi Ziraat Fakültesi Yayınları;1991. p.65.

Şenköylü N. Modern tavuküretimi. Edirne: Trakya Üniversitesi. Tekirdağ Ziraat Fakültesi. Hayvansal Üretim Bölümü; 2001.p.538.

Timmons MB, Gates RS. Relative humidity as a ventilation control parameter in broiler housing. Transactions of the ASAE 1987;30(4):1111-1115.

Tülücü K. Uygulamalı hidroloji. Adana: Çukurova Üniversitesi; 1988. p.3651.
Türkoğlu M, Sarıca M. Tavukçuluk bilimi (Yetiştirme, Besleme, Hastalıklar). Ankara; 2009. p.600.

Uğurlu N, Kara M. Yumurta tavuklarında havalandırma miktarına yerleşim sıklığı ve yapının ısı geçirme katsayısının etkisi. Selçuk Üniversitesi Ziraat Fakültesi Dergisi 2002;16(29):59-64.

Ugwuishiwu BO, Ugwu SN, Ohagwu CJ. Analysis of thermal control in animal buildings: a review. African Journal of Agricultural Science and Technology 2014; 2: 84-96.

Von Wachenfelt E, Pedersen S, Gustafsson G. Release of heat, moisture and carbon dioxide in an aviary system for laying hens. British Poultry Science 2001;42:171-179.

Wathes CM, Charles DR. Poultry housing,livestock housing. London: CAB International; 1994.p. 428.

Yahav S, Straschnow A, Plavnik I, Hurwitz S. Effect of diurnal cyclic versus constant temperatures on chicken growth and food intake. British Poultry Science 1996;37:43-54

Yum-Bir. Yumurta üreticileri merkez birliği. 2017a [cited 2017 Jan 02] Available from: http://www.yum-bir.org. 